\title{
ANALISIS KINERJA KEUANGAN BANK \\ SEBELUM DAN SESUDAH EKSPANSI \\ (Studi Kasus di BPR Siliwangi Tasikmalaya)
}

Oleh : Tedi Rustendi.

Fakultas Ekonomi - Universitas Siliwangi

\begin{abstract}
This research's objective has to known of financial performance betwen before and after expansion, and has it significant differentiation. Two samples data analized in time horizon of longitudinal with paired data in klasificated 'before and after'. Hypothesis testing used two tailed ' $t$ ' test of mean of two independent samples. The result shown that financial performance measured of ROA has not different, but used BOPO measurement, that has differentiation of financial performance betwen before and after expansion that done established branch office of bank. The conclusion of this research shown that established branch office of BPR Siliwangi as the expansion strategic has contribution on operational efficiency, but not influence on managerial efficiency.
\end{abstract}

Key word : financial performance, expansion

Abstrak.

Penelitian ini bertujuan untuk mengetahui kinerja keuangan bank sebelum dan sesudah ekspansi, dan apakah terdapat perbedaan signifikan kinerja keuangan sebelum ekspansi dan sesudah ekspansi. Penelitian dilakukan atas 2 sampel data dengan horison waktu longitudinal, sehingga meskipun sifat datanya berpasangan dalam kategori sebelum dan sesudah, tetapi sifat sampelnya independen. Berdasarkan hasil pengujian hipotesis dengan menggunakan uji beda atas rata-rata, ternyata kinerja keuangan yang diukur dengan rasio efisiensi manajerial tidak terdapat perbedaan antara sebelum dan sesudah ekspansi, sementara kinerja keuangan yang diukur dengan efisiensi operasi menunjukkan adanya perbedaan yang signifikan antara sebelum dan sesudah ekspansi. Dengan demikian, kesimpulan dari penelitian ini adalah ekspansi pasar melalui pembukaan kantor cabang di PT BPR Siliwangi tasikmalaya berkontribusi terhadap peningkatan efisiensi operasi, tetapi tidak berpengaruh terhadap efisiensi manajerial.

Kata Kunci : kinerja keuangan, ekspansi

\section{PENDAHULUAN.}

Salah satu masalah yang umum dihadapi oleh bank adalah pengembangan pasar di tengah-tengah persaingan yang semakin ketat. Pengembangan pasar tersebut sangat penting untuk diperhatikan mengingat strategi bisnis perbankan erat kaitannya dengan segmentasi pasar dan membuka pasar geografis yang baru. Umumnya strategi yang berkenaan dengan hal tersebut diarahkan selain untuk mencapai tujuan jangka panjang, juga untuk memberikan kemudahan, keamanan dan kenyaman nasabah dalam bertransaksi. Pearce II et al (2008) mengemukakan bahwa pengembangan pasar memungkinkan perusahaan untuk mempraktekan pertumbuhan terkonsentrasi dengan mengidentifikasi kegunaan produk yang ada 
saat ini, serta pasar baru yang didefinisikan dari segi demografis, psikografis, atau geografis.

Secara umum, pengembangan pasar mungkin hanya dilakukan sekedarnya dan tidak direncanakan dalam jangka panjang, misalnya dengan menambah cakupan area pemasaran oleh tenaga pemasaran (kredit maupun pendanaan), atau mengubah isi iklan (liflet, brosur, display) dan melakukan promosi kredit/simpanan dengan perubahan (sebagaian) spesifikasi untuk jangka waktu tertentu, sehingga produk yang dimaksud dapat berkembang lebih lanjut dalam daur hidup produk perbankan. Bagi bank umum atau BPR dengan permodalan yang kuat, pengembangan pasar lajim dilakukan dengan membuka Anjungan Tunai Mandiri pada beberapa titik yang dinilai strategis untuk menjangkau nasabahnya. Namun strategi demikian tidak dapat mengakomodasi seluruh kebutuhan nasabah akan pelayanan langsung bank.

Bentuk pengembangan pasar yang memerlukan perencanaan yang komprehensef termasuk penganggaran modal adalah dengan melakukan ekspansi berupa pembukaan kantor cabang, kantor cabang pembantu atau kantor kas. Pembukaan kantor baru diharapkan dapat menjangkau dan memberikan pelayanan yang lebih baik kepada nasabah/calon nasabah potensial. Disamping itu, dengan adanya kantor cabang/kantor kas di suatu wilayah geografis tertentu dapat membantu manajemen bank dalam upaya memenangkan persaingan pada segmen pasar tertentu.

Pandangan umum tersebut menginpirasi manajemen BPR Siliwangi Tasikmalaya untuk lebih mengukuhkan keberadaanya di wilayah Kota Tasikmalaya. Pertimbangan kelebihan dana yang berpotensi menganggur, dan ketatnya persaingan tidak hanya dengan BPR lain tetapi juga dengan bank umum yang merambah sektor UMKM serta koperasi simpan pinjam, mendorong manajemen bank untuk mengembangkan bisnisnya dengan segmentasi geografis yang sempit guna mencapai pertumbuhan terkonsentrasi dengan cara berbagi wilayah layanan dengan kantor pusat. Oleh karena itu kantor cabang baru dibuka diwilayah yang sama dengan kantor pusatnya yaitu di Kota Tasikmalaya.

Strategi bisnis dengan cara pengembangan pasar melalui ekspansi regional tersebut diharapkan dapat meningkatkan kinerja bank terutama dari aspek kinerja keuangannya. Hal tersebut dapat dipahami mengingat salah satu motifnya adalah investasi dengan memanfaatkan dana internal bank, serta mengoptimalkan dana pihak ketiga yang berhasil dihimpun dan cenderung menganggur. 
Bila memperhatikan fenomena jumlah kantor bank di Kota Tasikmalaya, dimana berdasarkan rilis Bank Indoensai sampai akhir tahun 2009 terdapat 24 kantor cabang bank umum, 13 kantor BRI Unit 13, dan 13 kantor BPR, dan jumlahnya bertambah pada tahun 2011 menjadi 31 kantor bank umum, 13 kantor BRI Unit, dan 21 kantor BPR, maka peta persaingan menjadi kompleks, tidak hanya antar BPR dan BRI Unit, tetapi juga persaingan terbuka terjadi dengan bank umum yang merambah sektor UMKM. Kondisi tersebut jelas menjadi tantangan tersendiri bagi BPR Siliwangi, dan menggambarkan bahwa terdapat risiko sulit tercapainya tujuan peningkatan kinerja keuangan bank melalui kebijakan ekspansi dengan membuka kantor cabang baru. Oleh karena itulah penulis tertarik untuk meneliti bagaimana kinerja keuangan bank sebelum dan sesudah ekspansi dilakukan.

Berdasarkan latar belakang penelitian yang diuraikan di atas, maka penulis merumuskan masalah penelitian sebagai berikut :

1. Bagaimana kinerja keuangan bank sebelum dan sesudah ekspansi dengan membuka kantor cabang baru?

2. Apakah terdapat perbedaan kinerja keuangan bank sebelum dan sesudah melakukan ekspansi dengan membuka kantor cabang baru?

Hasil penelitian ini dimaksudkan untuk memperkaya khasanah ilmu pengetahuan dalam bidang manajemen strategis, penganggaran, dan keuangan khususnya pada topik/materi strategi pengembangan pasar melalui ekspansi (pembukaan kantor cabang baru) di suatu wilayah dihubungkan dengan kinerja keuangan.

\section{KERANGKA KONSEPTUAL DAN HIPOTESIS.}

\subsection{Kerangka Konseptual.}

Bagi manajemen suatu perusahaan yang berorientasi pada kesejahteraan/ kemakmuran jangka panjang, capaian tahunan hanya merupakan sasaran-sasaran jangka pendek yang diarahkan untuk mencapai tujuan jangka panjang. Oleh karena itu, dalam pandangan manajemen strategis, manajemen cenderung memupuk modal internal dan menanamkannya kembali dalam investasi jangka panjang, dan memastikan bahwa strategi umum untuk memperoleh keunggulan kompetitif dapat diimplementasikan. Keunggulan kompetitif yang dimaksud secara konseptual berkenaan dengan penyediaan barang/jasa yang murah, atau berbeda/khusus untuk konsumen yang beragam, atau berupaya memenuhi kepuasan kelompok konsumen tertentu. Dalam pandangan Piarce II et al (2008), keunggulan kompetitif tersebut 
dapat dicapai melalui salah satu dari 3 (tiga) strategi umum, yaitu keunggulan biaya rendah, diferensiasi, dan memiliki daya tarik khusus bagi pelanggan.

Salah satu strategi umum yang banyak dipertimbangkan oleh bank yang sedang berkembang adalah pengembangan pasar. Piarce II et al (2008) mengemukakan bahwa pengembangan pasar dipilih bila manajer strategis dari perusahaan tersebut merasa bahwa produk-produk perusahaan saat ini akan diterima dengan baik oleh kelompok pelanggan baru. Pengembangan pasar yang dimaksud, seperti yang dikemukakan oleh Piarce II et al (2008) salah satu diantaranya adalah membuka pasar geografis tambahan melalui ekspansi. Dari aspek manajemen pemasaran bank, Kasmir (2008) mengemukakan bahwa strategi pertumbuhan untuk pasar baru dapat dilakukan salah satunya dengan strategi ekspansi pasar, yaitu strategi yang dilakukan bank dengan cara memasuki wilayah atau geografi baru.

Salah satu keputusan strategis dalam ekspansi pasar adalah membuka kantor cabang di wilayah geografis tertentu yang didasarkan pada keyakinan bahwa produk/jasa bank dapat diterima oleh nasabah baru. Keyakinan tersebut harus didasarkan kepada indikator yang teruji bahwa produk/jasa perbankan yang ditawarkan memiliki kualitas yang unggul. Kasmir (2008) menyebutnya sebagai faktor yang harus diperhatikan dalam kualitas jasa, yaitu service performance/perceived service dan costumer expectation.

Pembukaan kantor cabang dapat dilakukan pada wilayah yang sama (lokal) dengan kantor pusat atau di wilayah lain yang secara geografis jauh (regional/nasional/internasional) dari kantor pusat. Pemilihan wilayah geografis tersebut harus didasarkan kepada tujuan jangka panjang yang ingin dicapai oleh bank, dan membawa konsekuensi yang tidak ringan, misalnya dari aspek nilai investasi, pengendalian, penguasaan pasar, regulasi, dan perpajakan.

Salah satu keputusan ekspansi pasar yang umumnya dilakukan oleh bank berskala kecil (Bank Perkreditan Rakyat - BPR) adalah membuka kantor cabang di wilayah yang sama (kabupaten/kota) dengan kantor pusatnya (ekspansi lokal). Rose dan Hudgins (2010) mengemukakan bahwa kantor cabang dapat memberikan (hampir) semua jenis layanan perbankan seperti yang di berikan kantor pusatnya, nilai investasinya lebih murah daripada mendirikan perusahaan/bank baru, serta lokasi kantor cabang, desain, dan layanan yang tepat memberikan rasa konfiden, homeyness, dan privacy yang terjaga. Ekspansi demikian, didasarkan kepada pemikiran untuk berbagi wilayah/segmentasi nasabah antara kantor pusat dan 
kantor cabang, dan lebih dekat menjangkau nasabah, sehingga nasabah merasa nyaman dan aman dalam bertransaksi, dan dilayani lebih cepat dan tepat, sesuai dengan ekspektasi nasabah. Hal tersebut merupakan dimensi kualitas layanan perbankan yang harus diperhatian oleh setiap manajemen bank. Secara konseptual, Kasmir (2008) menyebutnya sebagai faktor yang mempengaruhi kualitas jasa, yaitu tangiable, empathy, reliability, responsiveness, dan assurance.

Berdasarkan konsep yang dikembangkan oleh pakar-pakar dibidang manajemen strategis, bentuk ekspansi lokal tersebut memiliki keuntungan tersendiri bagi bank berskala kecil (dalam hal ini BPR). Piarce II et al (2008) mengemukakan bahwa perusahaan-perusahaan kecil biasanya berhasil karena perusahaan-perusahaan itu melayani ceruk pasar yang sempit (fokus pasar), yaitu sampai sejauhmana suatu bisnis berkonsentrasi pada pasar yang terdefinisi secara sempit. Fokus sempit tersebut dapat didefinisikan secara geografis, atau berdasarkan fitur jenis produk, jenis target pelanggan, atau kombinasi dari hal-hal tersebut. Keberadaan bank yang lebih dekat dengan nasabah memberikan keuntungan dalam menjalin hubungan yang lebih erat antara bank dan nasabahnya sehingga bank memiliki informasi yang lengkap terkait profil nasabah. Sebagai contoh dalam manajemen kredit, Hünseler (2013 :79) mengemukakan bahwa bank yang memiliki hubungan erat dengan nasabahnya dapat emmpertahankan keunggulan kompetitif karena mampu mengambil keputusan secara tepat waktu dan melakukan intervensi pada saat strategi nasabah berubah atau pada saat kualitas kredit memburuk.

Kebijakan ekspansi pasar melalui pembukaan kantor cabang, pada dasarnya memiliki sasaran untuk meningkatkan volume transaksi perbankan melalui penambahan jumlah nasabah, serta frekuensi dan intensitas transaksi yang dilakukan nasabah. Bidang operasional bank yang menjadi acuan adalah pertumbuhan penghimpunan dana pihak ketiga dan penyaluran kredit. Pencapaian sasaran tersebut diharapkan dapat meningkatkan kinerja keuangan bank. Orientasi demikian sejalan dengan konsep yang dikemukakan oleh Breadley et al (2008) bahwa ekspansi kapasitas dalam bisnis merupakan keputusan yang mungkin berpusat salah satunya pada ramalan permintaan - selanjutnya dikemukakan bahwa berekspansi merupakan opsi riil yang diharapkan mendatangkan keuntungan dimasa datang.

Konsep demikian menunjukkan orientasi ekspansi pasar dengan membuka kantor cabang baru adalah untuk meningkatkan kinerja keuangan dalam dimensi 
profitabilitas. Rose dan Hudgins (2010) mengemukakan bahwa pengukuran kinerja bank yang berskala kecil dimana sahamnya tidak aktif diperdagangkan di pasar modal, cara untuk sampai pada nilai pasar menggunakan indikator rasio profitabilitas. Indikator rasio profitabilitas yang direkomenasikan oleh Bank Indonesia (1997) adalah Retrun On Asset - ROA, dan perbandingan Biaya Operasi dengan Pendapatan Operasi. Lebih lanjut, Rose dan Hudgins (2010) mengemukakan bahwa ROA merupakan indikator utama efisiensi manajerial yang menggambarkan kemampuan manajemen dalam menghasilkan laba dengan menggunakan/memanfaatkan seluruh aset - sedangkan - BOPO merupakan indikator tingkat efisiensi operasi, dimana setiap kenaikan nilai rasio efisiensi operasi mengindikasikan masalah dalam pengendalian biaya, atau penurunan dalam pendapatan. Formulasi efisiensi manajerial (ROA) dan efisiensi operasi (BOPO) dapat dirumuskan sebagai berikut :

$$
\begin{aligned}
& \text { ROA }=\frac{\text { Net Income }}{\text { Total Assets }} \quad \mathrm{X} 100 \% \\
& \text { Sumber : Rose dan Hudgins (2010) } \\
& \text { Operating Effisiency }=\frac{\text { Total Operating Expenses }}{\text { Total Operating Revenues }} \text { X 100\% }
\end{aligned}
$$

Sumber : Rose dan Hudgins (2010)

Rose dan Hudgins (2010) mengemukakan bahwa analisis lebih lanjut mengingatkan bahwa profitabilitas pada lembaga keuangan (baca : bank) bergantung kepada beberapa faktor, yaitu : financial leverage, operating leverage, pengendalian beban operasi, pengelolaan portofolio aset untuk menjaga likuiditas, dan pengendalian risiko.

Dengan demikian, pasca dilakukannya ekspansi, kinerja keuangan tidak secara mutlak diukur dengan kedua rasio tersebut. Faktor lain yang juga penting untuk dianalisis adalah pertumbuhan penghimpunan dana, penyaluran dana, dan kecenderungan perolehan laba berikut komponennya (pendapatan dan beban). Secara teoritis, keputusan ekspansi pasar akan menghasilkan tingkat profitabilitas yang lebih tinggi daripada sebelum melakukan ekspansi pasar.

\subsection{Hipotesis.}

Berdasarkan kerangka konseptual yang menggambarkan paradigma penelitian tersebut di atas, penulis merumuskan hipotesis sebagai berikut :

Terdapat perbedaan kinerja keuangan BPR Siliwangi Tasikmalaya sebelum dan sesudah melakukan ekspansi pasar melalui pembukaan kantor cabang. 


\section{METODE PENELITIAN.}

Tipe kajian dalam penelitian ini adalah analisis diferensiasi, oleh karena itu duduk perkara variabel dalam penelitian dioperasionalisasikan sebagai berikut :

1. Kinerja Keuangan Bank sebelum melakukan Ekspansi $\left(\mathrm{X}_{1}\right)$, dengan indikator $\mathrm{ROA}_{n 1}$. Ukuran yang digunakan adalah persen pada skala rasio.

2. Kinerja Keuangan sesudah melakukan Ekspansi $\left(\mathrm{X}_{2}\right)$, dengan indikator $\mathrm{ROA}_{\mathrm{n} 2}$. Ukuran yang digunakan adalah persen pada skala rasio.

Guna meminimalkan pengaruh faktor lain terhadap kinerja keuangan perusahaan setelah dilakukannya ekspansi, maka sampel ditetapkan berdasarkan pertimbangan urutan waktu yaitu $\mathrm{n}_{1}=36$ bulan sebelum dilakukannya ekspansi pasar (tahun $2007 \mathrm{~s} / \mathrm{d}$ 2009), dan $\mathrm{n}_{2}=36$ bulan sesudah dilakukannya ekspansi pasar (tahun 2010 s/d 2012). Cut-off data ditetapkan 31 Desember 2009 dengan pertimbangan bahwa ekpansi pasar yang ditandai mulai beroperasinya kantor cabang baru dilakukan pada awal tahun 2010 (Soft Opening Januari 2010).

Berdasarkan hipotesis penelitian yang menekankan uji diferensiasi antara 2 (dua) sampel $\mathrm{n}_{1}$ dan $\mathrm{n}_{2}$ pada pola pre and post, dengan horison waktu longitudinal, maka kedua sampel tersebut diperlakukan independen, dimana harga-harga $n_{1}$ (ROA sebelum ekspansi) tidak berhubungan dengan harga-harga $\mathrm{n}_{2}$ (ROA sesudah ekspansi). Analisis data berdasarkan perbedaan dua rata-rata dengan asumsi :

1. Data berdistribusi normal (sampel besar, $\mathrm{n}>30$ ).

2. Simpangan baku populasi sebelum ekspansi dan sesudah ekspansi dianggap tidak sama $\left(\sigma_{1} \neq \sigma_{2}\right)$ dan tidak diperhitungkan/tidak diketahui.

3. Statistik Uji yang digunakan adalah :

$$
t=\frac{\bar{x}_{1}-\bar{x}_{2}}{\left.\sqrt{\left(s_{1}^{2}\right.} / n_{1}\right)+\left(s_{2}^{2} / n_{2}\right)}
$$

Kaidah pengujian :

Terima $\mathrm{H}_{\mathrm{O}}$ bila : $-\left\{\left(\mathrm{w}_{1} \mathrm{t}_{1}+\mathrm{w}_{2} \mathrm{t}_{2}\right) /\left(\mathrm{w}_{1}+\mathrm{w}_{2}\right)\right\} \leq \mathrm{t}^{\prime} \leq\left\{\left(\mathrm{w}_{1} \mathrm{t}_{1}+\mathrm{w}_{2} \mathrm{t}_{2}\right) /\left(\mathrm{w}_{1}+\mathrm{w}_{2}\right)\right\}$

Tolak $\mathrm{H}_{\mathrm{O}}$ bila : $\mathrm{t}^{\prime}<-\left\{\left(\mathrm{w}_{1} \mathrm{t}_{1}+\mathrm{w}_{2} \mathrm{t}_{2}\right) /\left(\mathrm{w}_{1}+\mathrm{w}_{2}\right)\right\}$ atau $\mathrm{t}^{\prime}>\left\{\left(\mathrm{w}_{1} \mathrm{t}_{1}+\mathrm{w}_{2} \mathrm{t}_{2}\right) /\left(\mathrm{w}_{1}+\mathrm{w}_{2}\right)\right\}$

Dimana $: \mathrm{w}_{1}=\mathrm{s}_{1}{ }^{2} / \mathrm{n}_{1}$ dan $\mathrm{w}_{2}=\mathrm{s}_{2}{ }^{2} / \mathrm{n}_{2}$

$$
\mathrm{t}_{1}=\mathrm{t}_{(1-0.5 \mathrm{\alpha}),(\mathrm{n} 1-1)} \text { dan } \mathrm{t}_{1}=\mathrm{t}_{(1-0.5 \mathrm{\alpha}),(\mathrm{n} 2-1)}
$$

Sumber : Sudjana (1986 : 233)

Interpretasi : Bila hasil uji hipotesis ternyata terdapat perbedaan yang signifikan, maka dapat diartikan bahwa dalam kasus yang diteliti, ekspansi pasar berpengaruh terhadap kinerja keuangan bank. 


\section{HASIL PENELITIAN DAN PEMBAHASAN.}

BPR Siliwangi Tasikmalaya merupakan bank perkreditan rakyat berbentuk perseroan terbatas yang berdiri di Kota Tasikmalaya pada tahun 2005, milik Yayasan Universitas Siliwangi dengan modal disetor awal $\mathrm{Rp}$ 1.000.000.000,00. Lokasi bank berada di wilayah perkotaan dan berdekatan dengan beberapa bank umum yang sudah terlebih dahulu ada, sehingga bank berhadapan langsung dalam persaingan bisnis tidak hanya dengan BPR lain tetapi juga dengan bank umum. Oleh karena itu, dalam strategi bisnisnya, bank fokus kepada ceruk pasar yang sempit dengan mengutamakan kecepatan dan ketepatan layanan, serta berupaya agar nasabah merasa aman dan nyaman dalam bertransaksi.

Dalam kurun waktu 4 (empat) tahun sejak berdiri, bank memiliki total aset sebesar Rp 10.363.000.000,oo atau tumbuh 10 kali lipat. Di satu sisi funding, hal tersebut menggambarkan kinerja yang baik, tetapi bank dihadapkan pada masalah penyaluran dana dalam bentuk kredit yang hanya mencapai $55 \%$ (loan to deposit ratio). Kondisi tersebut menimbulkan masalah adanya dana yang menganggur, padahal dana tersebut diperoleh dari pihak ketiga yang mengandung biaya dana (cost of fund) yang tidak murah.

Faktor-faktor yang berkenaan dengan kompetitor dan melimpahnya dana pihak ketiga, mendorong manajemen menyusun rencana ekspansi pasar. Strategi bisnis yang diambil adalah membuka kantor cabang baru, memilih untuk fokus kepada ceruk pasar yang sempit, membagi wilayah kerja dengan kantor pusat agar lebih mampu menjangkau nasabah, dan menggunakan modal sendiri untuk membiayai ekspansi pasar tersebut. Alternatif ekspansi pasar yang dipilih adalah mendirikan kantor cabang di wilayah yang sama dengan kantor pusat.

Ekspansi pasar tersebut merupakan bentuk investasi jangka panjang yang diharapkan akan memberikan kontribusi dalam menunjang kinerja bank. Sesuai dengan prinsip ekspansi pasar, keberadaan kantor cabang baru diharapkan dapat meningkatkan volume bisnis bank baik dari aspek penghimpunan dana, maupun dari aspek penyaluran dana (kredit). Kegiatan bisnis tersebut bermuara pada tujuan untuk memperoleh laba sebagai nilai pengembalian dari investasi yang dilakukan.

Berdasarkan telaah terhadap dokumen hasil evaluasi Komisaris, sebagai pihak yang berwenang dalam menilai kinerja bank secara periodik (setiap semester), kinerja keuangan bank meliputi aspek penghimpunan dana, dan penyaluran dana (kredit), yang mempengaruhi faktor kecukupan modal, kualitas aktiva produktif, likuiditas, dan profitabilitas. Namun sesuai dengan tujuan dilakukannya ekspansi 
pasar, yang lebih berorientasi kepada peningkatan perolehan laba, maka pembahasan hasil penelitian lebih fokus kepada pengukuran profitabilitas. Adapun faktor pendukung seperti penghimpunan dana, penyaluran dana (kredit), aset, dan faktor kecukupan modal, kualiats aktiva produktif, dan likuiditas, dibahas berdasarkan analisis tren untuk menggambarkan pertumbuhannya.

Faktor-faktor kinerja keuangan yang sudah diolah berdasarkan laporan keuangan bank untuk periode $2007 \mathrm{~s} / \mathrm{d}$ 2012, yang terbagi 2 periode waktu, yaitu perode Tahun 2007 s/d 2009 sebagai periode sebelum ekspansi pasar, dan ; periode Tahun 2010 s/d 2012, disajikan sebagai berikut :

Tabel 4.1.

Penghimpunan Dana, Penyaluran Dana, Total Aset Dan Laba Bersih Periode Tahun 2007 s/d 2012

\begin{tabular}{|l|c|c|c|r|}
\hline Tahun & $\begin{array}{c}\text { Penghimpunan } \\
\text { Dana }\end{array}$ & $\begin{array}{c}\text { Penyaluran } \\
\text { Dana }\end{array}$ & $\begin{array}{c}\text { Total } \\
\text { Aset }\end{array}$ & $\begin{array}{c}\text { Laba } \\
\text { Bersih }\end{array}$ \\
\hline 2007 & 3.943 .947 & 2.897 .855 & 5.252 .148 & 105.865 \\
\hline 2008 & 6.203 .177 & 4.718 .592 & 7.495 .177 & 132.166 \\
\hline 2009 & $8,921.543$ & 5.525 .783 & 10.363 .871 & 209.228 \\
\hline 2010 & 11.868 .297 & 7.720 .733 & 14.086 .653 & 305.830 \\
\hline 2011 & 15.147 .135 & 10.173 .623 & 17.551 .411 & 251.783 \\
\hline 2012 & 19.426 .603 & 11.203 .946 & 22.503 .666 & 572.863 \\
\hline
\end{tabular}

Sumber : PT BPR Siliwangi Tasikmalaya

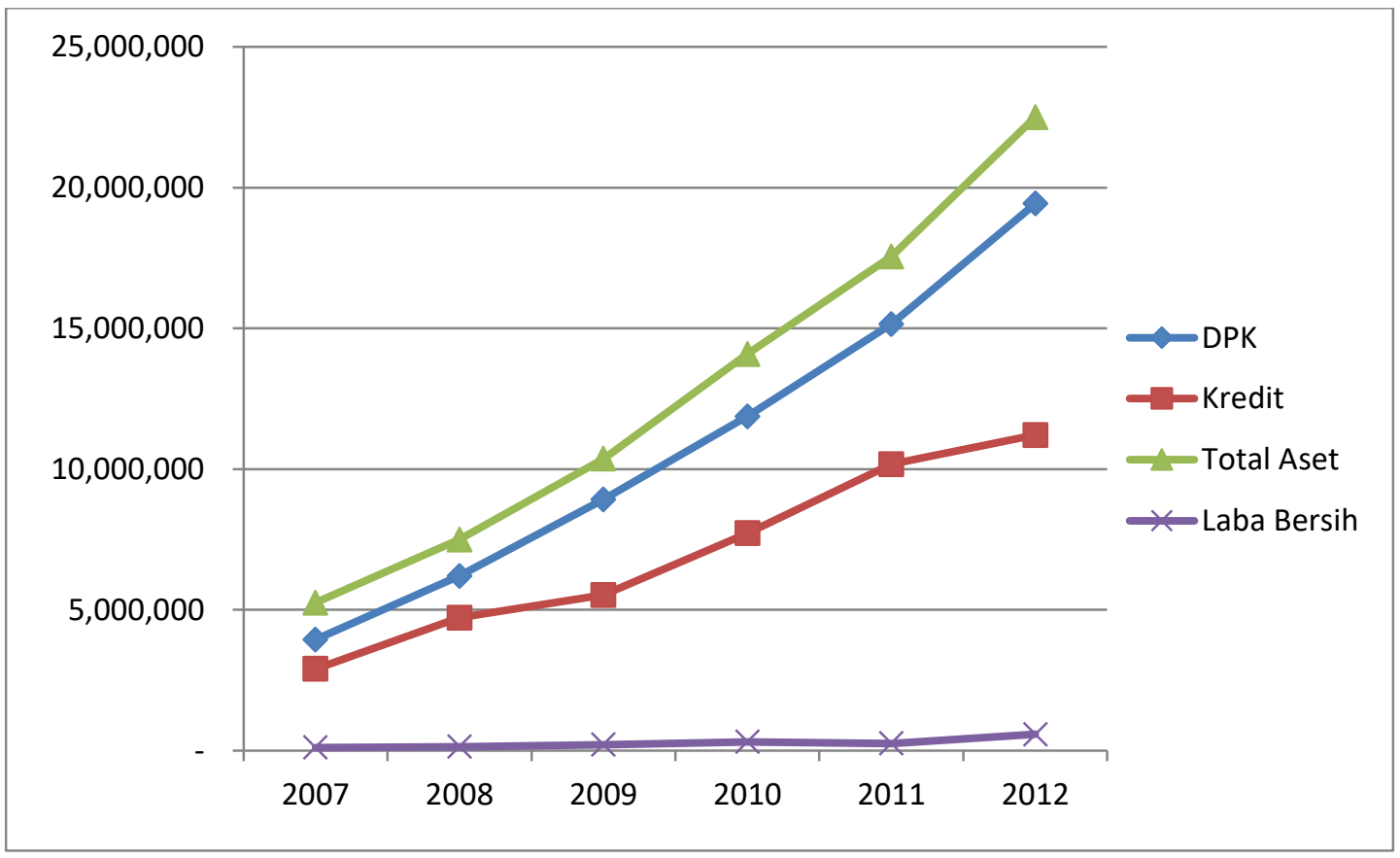

Diagram 4.1.

Penghimpunan Dana, Penyaluran Dana, Total Aset Dan Laba Bersih Periode Tahun 2007 s/d 2012 
Berdasarkan data tersebut di atas, aspek penghimpunan dana, penyaluran dana, aset, dan perolehan laba, secara umum memiliki tren yang semakin meningkat. Hal tersebut menunjukkan bahwa kebijakan ekspansi pasar melalui pembukaan kantor cabang baru memberikan kontribusi positif terhadap pertumbuhan perusahaan. Hal demikian sejalan dengan pandangan Rose dan Hudgins (2010) bahwa pembukaan kantor cabang bank dapat memompa/mendorong pertumbuhan bisnis. Orientasinya terutama dalam memaksimalkan penjualan (penyaluran kredit) dan menghimpun dana pihak ketiga. Dengan sendirinya, bila kedua hal tersebut berhasil dilakukan, maka akan berkontribusi dalam pertumbuhan aset bank.

Tabel 4.2.

CAR, NPL. ROA, BOPO, dan LDR

\begin{tabular}{|r|r|r|r|r|r|}
\hline TAHUN & \multicolumn{1}{|c|}{ CAR } & \multicolumn{1}{c|}{ NPL } & \multicolumn{1}{c|}{ ROA } & \multicolumn{1}{c|}{ BOPO } & \multicolumn{1}{l|}{ LDR } \\
\hline 2007 & 38,96 & 4,93 & 4,40 & 88,80 & 56,80 \\
\hline 2008 & 25,53 & 3,12 & 3,50 & 90,10 & 64,60 \\
\hline 2009 & 22,31 & 2,84 & 4,40 & 89,0 & 54,90 \\
\hline 2010 & 22,14 & 2,73 & 4,50 & 87,40 & 56,80 \\
\hline 2011 & 18,16 & 3,65 & 2,70 & 90,50 & 59,70 \\
\hline 2012 & 22,31 & 3,25 & 3,58 & 82,47 & 51,08 \\
\hline
\end{tabular}

Sumber : Diolah

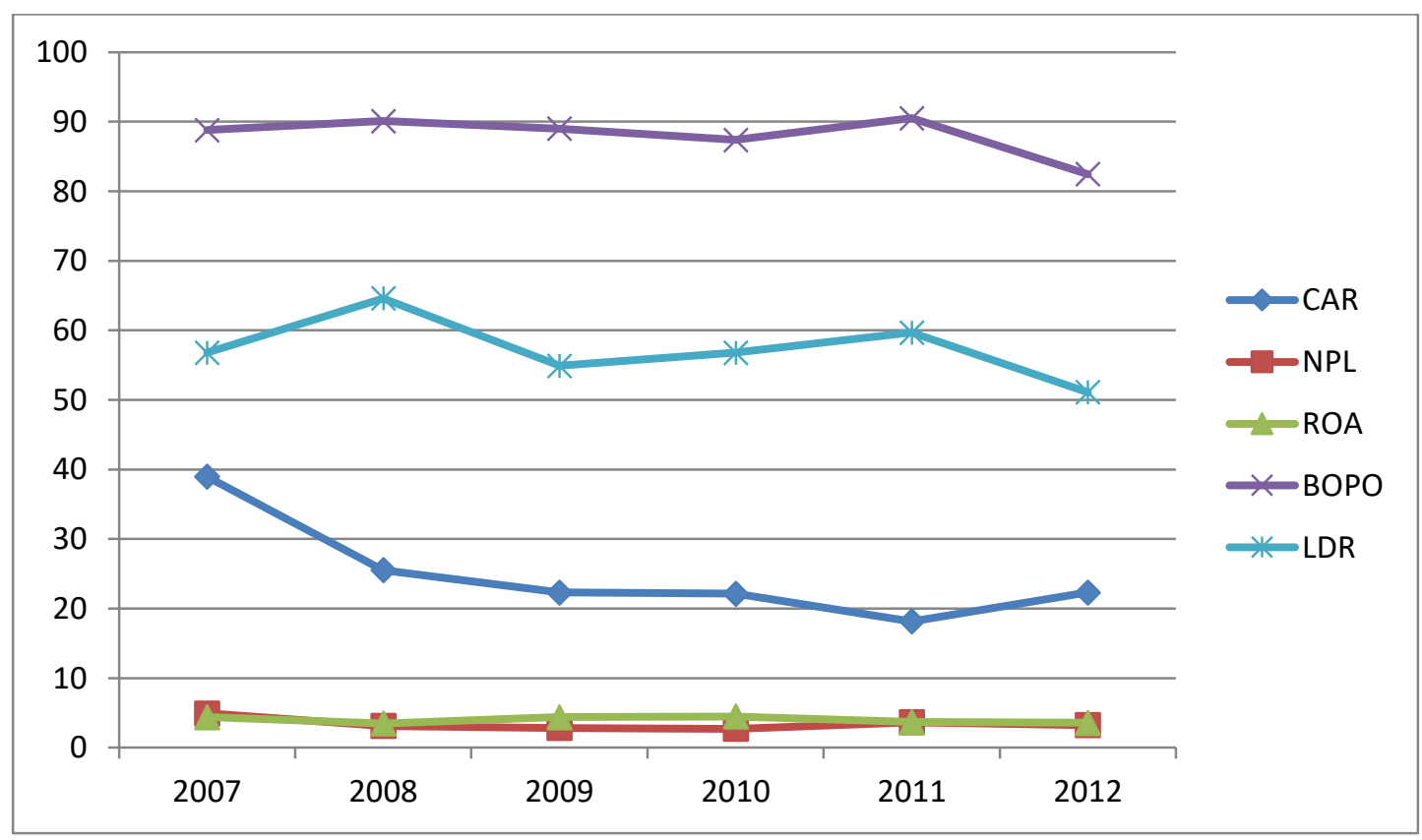

Diagram 4.2.

CAR, NPL, ROA, BOPO, LDR

Berdasarkan data tersebut di atas, dengan dilakukannya ekspansi pasar maka skala bisnis bank semakin besar dan membawa konsekuensi logis terhadap penurunan rasio kecukupan modal. Sekalipun demikian rasio kecukupan modal 
masih terbilang cukup tinggi dari batas minimal 8\% seperti ketentuan Bank Indonesia.

Sementara itu, ekspansi pasar ternyata belum mampu memperbaiki tingkat penyaluran kredit, bahkan ada kecenderungan tingkat LDR mengalami penurunan. Faktor yang menyebabkan kondisi tersebut adalah pertumbuhan dana pihak ketiga lebih tinggi daripada pertumbuhan kredit.

Dari aspek profitabilitas, ekspansi pasar kurang memberikan kontribusi terhadap efisiensi aset, dimana rasio ROA cenderung stagnan, sekalipun tingkat efisiensi operasi cenderung membaik (besaran rasio menurun), hal tersebut disebabkan karena tingkat kredit bermasalah yang cukup tinggi yang mengakibatkan tingkat pembebanan PPAP juga meningkat sehingga menimbulkan koreksi negatif terhadap laba. Sekalipun secara nominal laba bersih bank meningkat, namun pertumbuhan labanya lebih kecil daripada pertumbuhan aset, sehingga secara matematis, tingkat profitabiliatas bank tidak terkoreksi.

Tabel 4.3.

Faktor Kinerja Keuangan (Rasio Efisiensi Aset, dan Rasio Efisiensi Operasi)

\begin{tabular}{|c|c|c|c|}
\hline No & Faktor Kinerja & $\begin{array}{c}\text { Sebelum Ekspansi } \\
(2007 \text { s/d 2009) } \\
\%\end{array}$ & $\begin{array}{l}\text { Setelah Ekspansi } \\
\text { (2010 s/d 2012) } \\
\%\end{array}$ \\
\hline 1 & $\begin{array}{l}\text { Rata-rata ROA } \\
\text { Simpangan Baku ROA }\end{array}$ & $\begin{array}{r}3,39 \\
0,64\end{array}$ & $\begin{array}{r}3,60 \\
0,90\end{array}$ \\
\hline 2 & $\begin{array}{l}\text { Rata-rata BOPO } \\
\text { Simpangan Baku BOPO }\end{array}$ & $\begin{array}{r}89,30 \\
0,70 \\
\end{array}$ & $\begin{array}{r}86,79 \\
4,50 \\
\end{array}$ \\
\hline 3 & $\begin{array}{l}\mathrm{n}_{1} \\
\mathrm{n}_{2}\end{array}$ & 36 & 36 \\
\hline 4 & $\begin{array}{ll}\text { ROA : } & \mathrm{t}_{\text {statistic }} \\
& \text { Critical Value } \\
& \text { 2-tailed test }\end{array}$ & \multicolumn{2}{|c|}{$\begin{array}{c}1,1409 \\
\pm 9,9481 \\
-\end{array}$} \\
\hline & $\begin{aligned} \text { BOPO : } & \mathrm{t}_{\text {statistic }} \\
& \text { Critical Value } \\
& \text { 2-tailed test }\end{aligned}$ & \multicolumn{2}{|c|}{$\begin{array}{c}-3,3069 \\
\pm 2,02 \\
\text { Sig } \\
\end{array}$} \\
\hline
\end{tabular}

Sumber : Diolah

Berdasarkan hasil pengujian hipotesis, ternyata diperoleh hasil yang berbeda pada faktor efisiensi manajerial, dan efisiensi operasi., yaitu sebagai berikut :

1. Profitabilitas yang diukur dengan ROA :

Hasil pengujian hipotesis pada taraf nyata $5 \%$, ternyata tidak terdapat perbedaan rasio ROA sebelum ekspansi pasar dengan sesudah ekspansi pasar. Hal tersebut memiliki makna bahwa pada tingkat keyakinan 95\% ekspansi pasar melalui pembukaan kantor cabank tidak memberikan kontribusi positif terhadap peningkatan efisiensi manajerial. Faktor yang menyebabkan kondisi tersebut adalah : 
a) Rendahnya kemampuan manajemen dalam menyalurkan dana dalam bentuk kredit. Meskipun tren pemberian kredit meningkat, tetapi peningkatannya lebih rendah daripada dana yang berhasil dihimpun, bahkan pada tahun 2012 terjadi perlambatan penyaluran kredit. Secara kuantitatif, pertumbuhan pemberian kredit ( $\left.\beta_{\text {kredit }}\right)$ hanya sekitar Rp 1.716.871 rb per tahun, sedangkan pertumbuhan dana pihak ketiga $\left(\beta_{\mathrm{dpk}}\right)$ mencapai Rp 3.062.626 rb per tahun.

b) Penangan kredit macet yang stagnan $\left(\beta_{\text {npl }}\right)$ /- 0,0019 limit o yang menggambarkan peningkatan jumlah kredit yang diberikan ternyata diikuti dengan meningkatnya jumlah kredit bermasalah.

2. Profitabilitas yang diukur dengan BOPO

Hasil pengujian hipotesis pada taraf nyata $5 \%$, ternyata terdapat perbedaan Rasio BOPO sebelum ekspansi pasar dengan sesudah ekspansi pasar. Hal tersebut mengandung makna bahwa ekpansi pasar melalui pembukaan kantor cabang memberikan kontribusi signifikan terhadap peningkatan efisiensi operasi. Faktor yang menyebabkan kondisi tersebut adalah Pertumbuhan pendapatan operasional lebih tinggi daripada pertumbuhan biaya operasional, dimana peningkatan biaya overhead pokok yang meliputi sunk cost, biaya dana, dan biaya tenaga kerja dapat ditutup dengan peningkatan pendapatan usaha pokok bank.

\section{SIMPULAN DAN SARAN.}

\subsection{Simpulan.}

Kebijakan strategis bank dalam ekspansi pasar dengan membuka kantor cabang bank yang baru dapat meningkatkan pertumbuhan bisnis, baik dari aspek penghimpunan dana, maupun dari aspek penyaluran dana dalam bentuk kredit. Kedua aspek tersebut berkontribusi terhadap pertumbuhan aset yang signifikan. Namun demikian, dari pembahasan dapat diketahui juga bahwa pertumbuhan kredit mengalami perlambatan pada tahun 2012, dimana kondisi tersebut kontradiktif dengan pertumbuhan dana pihak ketiga yang justru meningkat tajam. Hal tersebut mengindikasikan adanya potensi dana yang menganggur yang kemungkinan akan mempengaruhi tingkat produktifitas aset (efisiensi manajerial) dalam menghasilkan laba.

Pada tingkat keyakinan 95\%, kebijakan strategis bank dalam ekspansi pasar dengan membuka kantor cabang bank yang baru, ternyata memberikan kontribusi 
signifikan terhadap tingkat efisiensi operasi, tetapi tidak mempengaruhi tingkat efisiensi manajerial.

\subsection{Saran.}

Bank sebaiknya melakukan penaganan khusus untuk mengatasi kredit bermasalah, dengan cara membentuk Tim Penyelesaian Kredit Macet dipimpin oleh Direktur Operasional. Keberadaan tim yang dimaksud terbukti efektif di bank yang sudah menerapkannya. Bank sebaiknya mengimbangi pertumbuhan dana pihak ketiga dengan strategi baru dalam pengembangan pasar. Fokus yang belum digarap oleh bank adalah pengembangan produk/jasa bank yaitu kredit. Berdasarkan telaah kebijakan kredit, ternyata bank tertinggal dari pesaingnya (bank umum) terutama dalam penetapan suku bunga kredit, dan biaya pengurusannya. Spread yang lebih rendah dan pelayanan kredit yang lebih cepat menjadi faktor yang perlu diupayakan.

Kompleksitas penilaian kinerja keuangan bank dari aspek efisiensi manajerial memberikan informasi yang berguna terutama dalam identifikasi faktorfaktor yang kemungkinan mempengaruhinya. Oleh karena itu, penelitian selanjutnya dpat lebih difokuskan kepada analisis faktor-faktor yang mempengaruhi kinerja keuangan terutama terhadap efisiensi manajerial.

\section{REFERENSI}

Agnes Sawir. 2008. Analisis Kinerja Keuangan Dan Perencanaan Keuangan Perusahaan. Penerbit : Gramedia Pustaka Utama. Jakarta.

Bank Indonesia 2006-1. Peraturan Bank Indonesia No 8/19/PBI/2006 tentang Kualitas Aktiva Produktif dan Pembentukan Penyisihan Aktiva Produktif Bank Perkreditan Rakyat.

. 2006-2. Surat Edaran No 8/28/DPBPR/2006 tentang Kewajiban IVPenyediaan Modal Minimum Bank Perkreditan Rakyat.

1997. Tata Cara Penilaian Tingkat Kesehatan Bank Perkreditan Rakyat, SK Direktur BI no 30/12/KEP/DIR berikut SE BI no 30/3/KEP/DIR tahun 1997

Breadley, Richard A., dan Stewart C. Myers, dan Alan K. Marcus, diterjemahkan oleh Yelvi Andri Zaimur. 2008. Dasar-dasar manajemen Keuangan Perusahaan. Penerbit : Erlangga. Jakarta.

Brigham, Eugene F., and Joel F. Houston. 2009. Fundamentals of Financial Management, $12^{\text {th }}$ edt. South-Western, Cengage Learning. Ohio 
Hünseler, Michael. 2013. Credit Portfolio Management ; A Practitioner's Guide to The Active Management of Credit Risk. Penerbit : Palgrave Macmilan, New York - USA.

Kasmir .2008. Pemasaran Bank, edisi revisi, cetakan ketiga. Penerbit : Kencana (Prenada Media Grup). Jakarta.

2004. Bank Dan Lembaga Keuangan Lainnya. Jakarta. Penerbit : Raja Grafindo Persada.

Malayu S. P. Hasibuan. 2006. Dasar-dasar Perbankan. Jakarta. Penerbit : PT. Bumi Aksara.

Piearce II., John A., dan Richard B. Robinson, diterjemahkan oleh Yanivi Bachtiar dan Christine. 2008. Manajemen Strategis ; Formulasi, Implementasi, dan Pengendalian, Buku 1 Edt 10. Penerbit : Salemba Empat, Jakarta.

Rose, Peter S., and Sylvia C. Hudgins. 2010. Bank Management And Financial Servives, $8^{\text {th }}$ edt., Penerbit : McGraw Hill/Irwin. New York.

Sudjana. 1986. Metoda Statistika, edisi ke-4. Penerbit : Tarsito. Bandung

Sumardi Ismail. 2005. Aspek keuangan ; Analisis Laporan Keuangan Masa Lalu Dan Proyeksi. Jakarta. Penerbit : Lembaga Pengembangan Perbankan Indonesia LPPI.

Undang Undang No 10 Tahun 1998, Perubahan atas Undang Undang No 7 Tahun 1992 tentang Perbankan 